\title{
The Social Characteristics of Volunteers in Jordan: A Field Study through the Maintenance Project of Poor Families Houses in Irbid City
}

\author{
Safwat M. Al-Rousan \\ Associate Professor of Sociology \& Social Services \\ Balqa Applied University/ Ajloun University College \\ Department of Social Sciences
}

\begin{abstract}
This study aimed to examine the social characteristics of volunteers in Jordan, by studying the characteristics of volunteers in the maintenance project of poor families' houses in Irbid city and identify the motivations behind this volunteer work, and then determine if there are statistically significant differences in the volunteer work motivations, due to the variable of social type or gender. The study adopted the descriptive studies method and the social survey methodology. A questionnaire was prepared and distributed on the study sample that consists of (63) volunteers to identify their major social characteristics and features and to ask them about the forces that motive them to be involve in the volunteer work. After that, the T-Test will be implemented to show the statistical differences in the volunteer motivations, according to the gender variable. The results on the social characteristics of volunteers came to show that majority of the study sample members are men, from the age group (41-50), of middle-income, and have their own job. The results also showed that (65\%) of the study sample members are retirees and camp residents, where the majority of them are married and don't have high degrees. In addition, the study showed that (54\%) of the study sample members are continuously active in the volunteer work. The study showed that order of motivations towards volunteer work was as follows: (social, cultural, human, ethical, then the personal, and finally the religious). The results also showed that arithmetic means for the volunteer motivations linked to the personal, social, cultural, ethical, human and religious dimensions showed nonexistence of statistically significant differences at the level $(\alpha \leq 05)$, due to the difference in
\end{abstract}

Keywords: gender or social type, social characteristics, volunteer work, volunteer motivations

\section{Preliminary Introduction}

Volunteering as a concept involves; in its essence the existence of human efforts that made by society members, as an individual or as a group, based primarily on the desire and conscious or unconscious self-motivation, and the volunteer doesn't aim through it to achieve a financial reward or a special profit, but instead he or she seeks to gain a sense of belonging to the society and take on some societal responsibilities that contribute to meeting urgent social needs or serving one of the issues that society suffered from, and its a fundamental motivation of development forces in its comprehensive concept economically, politically, socially, and culturally and its also an indication on the vitality of society. In addition, it has a role in strengthening the social ties and reducing the categorical differences between the society members and between the social formations at its different forms, views, and shapes (Al-Khatieb, 2002: 11-12).

The concept of social development extends to include several areas that interact with each other, such as education, health, housing, and the social security, but the serious development must take into account the society systems, its values, its customs, and its social and cultural heritage, in order to benefit from it in encouraging and activating whatever its fruitful, from the standpoint of society and the state, and then removing and addressing whatever it stands in the way of this society progress (UN, 2002). If the simple definition of development was to seek a deliberate and positive change, which is connected to a specific place and time for improving and facilitating the lives of individuals in pursuit for social well-being, emphasizing that human is the main foundation of development and its goal. If providing adequate housing for individuals was one of the basic conditions for improving their lives and its quality, therefore housing considers one of priorities in the ladder of basic human needs, and its undoubtedly one of the most important goals that development schemes seek to achieve.

The Ministry of Social Development in Jordan has paid close and broad attention during its effort to improve the conditions of poor families, and one of its plans was to develop program to create suitable housing for these families. The focus has been on families that live in the marginal areas; with non-permanent housing in order for these families to live in adequate sanitary housing, in accordance with their economical and social realities, and the number of their members. 
In this regard, the ministry strategy was launched in two-way, the first is to provide new housing and to expand on the existing one, and the other one depends on maintaining the existing houses and improve its reality, where this strategy was drawn up on the basis of a partnership between the public, private, and local sector (Ministry of Development, 2003:310).

The Directorate of Social Development in Irbid city, as part of the Ministry of Development worked on the ministry's program to maintain the housing of poor families, where it carried out maintenance work that included twenty houses in one of the city's poorest neighborhoods, Al-Turkman in order to improve the housing conditions of these families, and improve their life quality; at a lower financial cost and with less burden on the government budgets, which makes it possible to expand it to include a larger segment of poor families in the Jordanian society (Ministry of Development, 2003:213). However, the work method of these projects came with the semi-total reliance on the efforts of volunteers and the local communities in the support and implementation, where the Directorate only played the coordinator and supervisor role on the implementation of these jobs, since it has the sufficient information and studies about poor families in the neighborhood. A good number of volunteers and from different segments of society participated in the project, and in carrying out its jobs, operations, and tasks (World Bank, 2006).

The project as a whole is an initiative that aimed to make all parties cooperate to implement a series of special activities for the maintenance of a number of houses. The maintenance work included jobs that aimed to rehabilitate and fix these houses to become suitable for the lowest level of human habitation, and these types of works are represented in the restoration of ceilings, paint, tiles, and the electrical and sanitary extensions, as well as any possible actions that enter the joy and pleasure on inhabitants' hearts.

\section{Study Problem \& Questions}

The activation of local communities participation role based on volunteer work by individuals and voluntary institutions that have a long history of volunteering in the local communities, in various fields, and with multiple sectors may be a key dimension in the success of any project or any initiative that reaches the local community they work in (Forums of Jordan people/ Website).

In spite of the importance of project in development, study is an attempt to identify the most important social characteristics of people volunteering in this project, in an effort to understand the nature of volunteers' social and personal components in Jordan. The study also tried to determine the reasons and motives that drive these segments to volunteer, such as social, religious, ethical, and human. The study then tried to reveal the differences in volunteering motivations, according to the gender variable.

The study problem was represented in the following question:

- What are the social characteristics of volunteer people in Irbid province?

- What are the main motives behind volunteering?

- Are there any statistically significant differences at level $(\alpha \leq 05)$ between the volunteering motivations in Irbid city, due to the gender variable?

\section{Study Importance}

The importance of this study comes in addressing the most important personal characteristics of the people volunteering in Jordan, and in addressing the reasons, motives, and forces that lead them to the volunteer work, where there is a clear scarcity in this type of sociological studies in Jordan.

\section{Theoretical Framework}

\section{- Volunteering:}

Volunteering or volunteer work considers one of the important topics in the contemporary human and social philosophy, where it's the comprehensive development pillar in society and it's the most essential supporter of institutions in the success of its programs, in upgrading its services level, and in promoting the grouped identity of society members. It must be emphasized that there are multiple motives for volunteering, such as the intellectual motives that are related to the ideas and principles which volunteer believe in, the psychological motives associated with individual's need to feel a sense of belonging and to practice the hobbies, the religious motives that believe in working for the benefit of public interest, and the social motives that believe in the general interest (Al-Preem, 2015).

Volunteering according to social workers is the effort that individual makes for the society, for the sake of an institution, or for a particular group without expecting a financial reward for his or her efforts, whether its a selfmade effort or money, willingly for the happiness of others, where the volunteer work has developed in Jordan at several aspects, with different type and gender of volunteers (Halallat, 2018).

\section{- Volunteer:}


The volunteer is a positive person who tries to help in any area where he or she can achieve a task or a job, and seeks to work with society members to advance to a better life that will help them and meet their needs. Volunteer work has an important positive effects where it provide the opportunities for cooperation between the community members, it develops in the individual a state of respect for others, and the appreciation of useful work.

In addition, it provides the volunteers with field and administrative expertise in the social charitable work, which give them an opportunity to train on the participation in business and decision-making. Work is also a valuable and idealistic way that gives the self a sense of satisfaction and belonging to the society and geography to contribute to overcome many diseases of the decade, such as depression, feelings isolated, and the social and psychological pressures (Al-Khatib, 2002:24).

Whoever contemplates the volunteer work finds it subject to the individuals' conviction and their sense of responsibility toward their society and social structure, and basically towards work and volunteering in it. Organizing in volunteer work consider a source of its strength, especially when the volunteer faces obstacles and difficulties that prevent him or her from continuation, which may lead the volunteer to select more improvisational and ill-considered methods that complicate the work by adopting the administrative hierarchy in decision-making or principle of consultation which is far from selfishness. Motivation also plays a major role in maintaining the volunteer and exerting his best efforts to serve the work with dedication and tirelessness by allowing him to participate in the decision-making process and have dialogue with transparency and clarity (Teamwork, 2008).

There have been many interpreted theories of volunteering in the social sciences, there are the functional theory and the structural theory but the researcher believes that social exchange theory might be the closest to the interpretation of behavior associated with volunteering, where this theory tries to focus on the social individual actions and on the interests associated with these actions and behaviors. There is an interest associated with mutual and commutative relationships, where the continuation of individual or group with the action and relationship is linked organically with the continuation level of obtaining the benefits. The theory focuses on evaluating actions, the more a person or group evaluates the actions positively, the more they will continue to do the same action, while the issue is inversely linked to the negative assessment of unwanted behavior. The achievement of moral gains by the volunteer is linked with the appreciation and respect of society, which increases the gratitude of volunteers to evaluate their actions positively and therefore, motivates them to continue in this volunteer work (Halallat, 2018).

Several studies have referred to the volunteering topic, for example the study of (Zubaidi, 2006) about the trends of Jordanian University students towards volunteering showed that male volunteering in Jordan is more than female, which contradict with the (Halallat, 2018) study about the obstacles of volunteer work in Jordan who found that females are willing to volunteer just like males. The study of (Al-Preem, 2015) on the determinants of volunteer work among University of Jordan students showed that most important are the social and economical determinants, while the study of (Al-Bakkar, 2016) about the obstacles of volunteering among young students at the University of Jordan, found that lack of knowledge about volunteer work is the main obstacle of volunteering. Study of (AlShahwan, 2017) that entitled "The role of Jordanian television in the development of volunteer work, from the standpoint of young people showed a turnout and demand by Jordanian youth on the volunteer work, due to the existence of many problems that face the Jordanain society.

It remained to say that volunteering is any type of work individuals perform to serve the community and it's a service that provided voluntarily with no regard to its financial returns. We can also say that volunteers in Jordan have characteristics that distinguish them from other members of the community, and have forces and reasons which motivate them towards this volunteer work. This study is an attempt to understand and investigate these issues, motives, and its effects on the volunteer work.

\section{Study Methodology \& Procedures}

\subsection{Approach used:}

This research belongs to the descriptive studies, which rely on the social survey method to answer its questions.

\subsection{Study Population:}

The study society is made up of all 63 persons who volunteered to work on the project of maintaining the poor families' houses in Irbid.

\subsection{Study Tool:}

The researcher designed a questionnaire that contains data related to the characteristics of volunteers and their personal attributes, which included in the first dimension (gender, age, income, work type, work status, place of residence, marital status, educational level, and number of volunteering times) since its represent the most important social characteristics and features. 
The second dimension included the motives and reasons behind volunteering (the personal motives, social and cultural motives, human and ethical, and religious motives), where the study sample members were asked directly about their motives without giving details. The tool sincerity has been confirmed by presenting it on a group of arbitrator professors in the field of social services and sociology to verify its validity.

\subsection{Statistical Methods:}

The study relied on the recurrences or frequencies and arithmetic means, in relation to the first and second parts of the questionnaire to answer the first and second questions of the study, but to interpret and answer the third question the study depended on the T-test to show the statistical differences between the males and females motives and measure the gender variable.

\section{Study Results \& Discussion}

\subsection{Study Results:}

\section{First: Results related to the social characteristics of study society}

Table (1) relative distribution for the social characteristics of study society

\begin{tabular}{|c|c|c|c|c|}
\hline Number & Variables & Categories & Frequencies & $\%$ \\
\hline 1 & Gender & $\begin{array}{l}\text { Man } \\
\text { Women }\end{array}$ & $\begin{array}{l}38 \\
25\end{array}$ & $\begin{array}{l}60.3 \\
39.7\end{array}$ \\
\hline 2 & Age & $\begin{array}{l}20-30 \\
31-40 \\
41-50 \\
51 y r s \& \text { more }\end{array}$ & $\begin{array}{l}20 \\
13 \\
27 \\
3\end{array}$ & $\begin{array}{l}32 \\
20.5 \\
42.8 \\
4.7\end{array}$ \\
\hline 3 & Income & $\begin{array}{l}200-300 \\
301-400 \\
401-500 \\
501 \text { JDs \& more }\end{array}$ & $\begin{array}{l}5 \\
30 \\
7 \\
21\end{array}$ & $\begin{array}{l}8 \\
47.7 \\
11 \\
33.3\end{array}$ \\
\hline 4 & Work Type & $\begin{array}{l}\text { Student } \\
\text { Employee } \\
\text { Self Employees }\end{array}$ & $\begin{array}{l}16 \\
12 \\
35\end{array}$ & $\begin{array}{l}25.3 \\
19.3 \\
55.5\end{array}$ \\
\hline 5 & Work Status & $\begin{array}{l}\text { Employed } \\
\text { Retired }\end{array}$ & $\begin{array}{l}22 \\
41\end{array}$ & $\begin{array}{l}35 \\
65\end{array}$ \\
\hline 6 & Place of Residence & $\begin{array}{l}\text { City } \\
\text { Village } \\
\text { Camp }\end{array}$ & $\begin{array}{l}20 \\
13 \\
30\end{array}$ & $\begin{array}{l}31.7 \\
20.6 \\
47.7\end{array}$ \\
\hline 7 & Marital Status & $\begin{array}{l}\text { Single } \\
\text { Married }\end{array}$ & $\begin{array}{l}29 \\
34\end{array}$ & $\begin{array}{l}46 \\
54\end{array}$ \\
\hline 8 & Education Level & $\begin{array}{l}\text { High School Diploma } \\
\text { Community College } \\
\text { University Graduate } \\
\text { Higher Education }\end{array}$ & $\begin{array}{l}33 \\
8 \\
20 \\
2\end{array}$ & $\begin{array}{l}52.4 \\
12.7 \\
31.7 \\
3.2\end{array}$ \\
\hline 9 & Number of volunteering & $\begin{array}{l}\text { One Time } \\
\text { More Than One } \\
\text { Always }\end{array}$ & $\begin{array}{l}15 \\
14 \\
34\end{array}$ & $\begin{array}{l}23.8 \\
22.2 \\
54.0\end{array}$ \\
\hline
\end{tabular}

Table (1) which related to the social characteristics and features of study society shows that majority of study sample members are men with $(60.3 \%)$, which is consistent with the majority of studies that addressed volunteering in the Jordanian society, and see that males volunteer more than females, which is consistent with Al-Zubaidi study. The results also showed that majority of sample members are within the age group (41-50) years at $(42.8 \%)$, and they are from those whose incomes between (301-400) at (47.7\%), and the majority of society members works in free jobs and makes (55.5\%). The results also showed that (65) \% of the study society members are retirees, $(47.7 \%)$ are camp residents, (54\%) of them are married, and (52.4\%) of them don't have high educational degrees. In addition, the study showed that $(54 \%)$ of the study society members are constantly active in the volunteer work. 


\section{Second: the motives of volunteering in Jordanian society}

Table (2) relative distribution for volunteer motivations of the study society

\begin{tabular}{l|l|l|l} 
Number & Motives & Frequencies & \% \\
\hline 1 & Personal & 11 & 17.5 \\
\hline 2 & Social \& Cultural & 26 & 41.3 \\
\hline 3 & Human \& Ethical, & 19 & 30.1 \\
\hline 4 & Religious & 7 & 11.1
\end{tabular}

Table (2) which is related to the distribution of sample members according to their motivations toward volunteering shows that majority of volunteers get involve in volunteer work due to social and cultural motivation at (41.3\%), the human and ethical motivation comes in second place with (30.1\%) while in third place comes the personal motives with (17.5\%), and finally the religious motivation with (11.1\%).

\section{Third: volunteering motives according to the gender variable}

Table (3) T-test results for the significance of difference in motivations towards volunteering, due to gender

\begin{tabular}{|c|c|c|c|c|c|}
\hline Motives & Gender & Mean & STDEV & $\begin{array}{l}\text { Calculated } \\
\text { Value }\end{array}$ & Sig \\
\hline Personal & $\begin{array}{l}\text { Men } \\
\text { Women }\end{array}$ & $\begin{array}{l}2.25 \\
2.27\end{array}$ & $\begin{array}{l}0.25 \\
0.30\end{array}$ & 0.281 & 0.779 \\
\hline Social \& Cultural & $\begin{array}{l}\text { Men } \\
\text { Women }\end{array}$ & $\begin{array}{l}2.32 \\
2.29\end{array}$ & $\begin{array}{l}0.36 \\
0.24\end{array}$ & 0.290 & 0.771 \\
\hline Human \& Ethical & $\begin{array}{l}\text { Men } \\
\text { Women }\end{array}$ & $\begin{array}{l}2.28 \\
2.29\end{array}$ & $\begin{array}{l}0.24 \\
0.25\end{array}$ & -0.069 & 0.940 \\
\hline Religious & $\begin{array}{l}\text { Men } \\
\text { Women }\end{array}$ & $\begin{array}{l}2.30 \\
2.28\end{array}$ & $\begin{array}{l}0.33 \\
0.29\end{array}$ & 0.288 & 0.942 \\
\hline Motives Overall Level & $\begin{array}{l}\text { Men } \\
\text { Women }\end{array}$ & $\begin{array}{l}2.28 \\
2.27\end{array}$ & $\begin{array}{l}0.20 \\
0.21\end{array}$ & -0.043 & 0.966 \\
\hline
\end{tabular}

Table (3) shows the arithmetic means and standard deviations of T-test for the differences between the motivations of volunteering, due to the gender variable where the results of arithmetic means for the motivations of volunteering which associated with the personal, social and cultural, ethical and human, and religious motive showed non-existence of statistically significant differences at the level $(\alpha \leq 05)$, due to the difference of gender.

\subsection{Results Discussion:}

The study results about the most important social characteristics of volunteer people in Jordan showed that majority of volunteers are men, which is consistent with the majority of studies on volunteering at the Jordanian society that found males are more likely to volunteer than females, which aligns with the Zubaidi study and perhaps it's a normal thing in a society where the masculinity values prevail. Results also showed that volunteers belong to the age group between (40-50 yrs), which is a normal thing that associated with the social awareness and grows with age, and this age group have more spare time and have social aspirations that associated with elections and social leaderships.

The results related to economical activity type of volunteers in Jordan showed that they belong to the middle class income who work in free occupations, such as trade, handcraft, and vocations which express the reality of economical activity among the Jordanian society members as a whole, especially the members and residences of camps where according to the study results high percentage of them are volunteers, and often the volunteering culture in Jordan is greater among camp members, as a result of their contact with many of the institutions that work in this field of volunteering.

The study showed that most often the volunteers are retired from work and therefore its normal for them to have a large free time which push them to work in the social and volunteer field, and it's a must to emphasize that early retirement culture in the Jordanian society is more widespread among males than females, and often retirees are from the army which justified that most volunteers don't carry degrees. The results also showed that majority of volunteers are married, which is normal if it was associated with age in the Jordanian society, where it's rare for a person to reach the age of 40 without getting married. 
In regard to the motives behind volunteering or the reasons that make the society members go toward volunteering, the study showed that main reason for volunteering in Jordan return to social and cultural motives, where in the Jordanian society social activities, especially in the local communities consider one of the great ethics that give the individuals great values among their relatives, and among those who surround them in their social environment, due to the fact that serving people according to the standard of Jordanian society consider high ethical values that have high social respect and consideration.

The study results showed that human and ethical motivation is also an important reason that make people go toward volunteering, and it based on convictions in the human rights concept and the social solidarity values, which still in the Jordanian society represent a symbol of identity for the society members who deeply believe in the equality between all people, while the study showed that personal and religious motivation wasn't an influential factor in pushing the society members to volunteer.

The study results also showed that gender variable isn't significant in relation to the motivations of volunteering among the members of Jordanian society, which is normal since the majority of people; men and women belong to the same ethical system, and look at the social reality with an equal view. In addition, this view shows that Women in the Jordanian society enjoy a good level of freedom to work, move, and interact positively with the different issues of society.

\section{References}

- Al-Aryani, Ameen (Jan., 2002), "Housing for the Poor Categories In Sana City", U.N Human Settlements Program, Amman, Jordan

- Al-Bakkar, Asem, Al-Adayleh, Lubna \& Al-Nabulsi, Hanaa (2016), "The obstacles of volunteer work among the University of Jordan young students", Dirasat Journal, University of Jordan.

- Al-Khatib, Abdullah (2002), "Volunteer Group Work", Open University of Jerusalem, Amman, Jordan

- Al-Preem, Rasha (2015), "Limitations of Volunteer work among the Jordanian University Students, Unpublished Master Thesis, University of Jordan.

- Al-Shahwan, Mohammed (2017), "Role of Jordanian Television in the Development of Volunteering, from the standpoint of Youth", All Jordan Youth Association as a model, Unpublished Master Thesis, Middle East University.

- Directorate of Social Development (2008), Irbid, Jordan.

- Halallat, Khalil (2018), "Obstacles to Volunteering in Jordan", Jordan Journal of Social Sciences, University of Jordan, Vol. 11, No. 1

- Jordan Members Forums, website, http://www.jor-son.com/vb/showthread.php?t=51085

- Ministry of Social Development (2003), "Strategic Plan 2004-2006", Ministry of Development, Amman, Jordan.

- Mokhtar, Abdulaziz Abdullah (1995), "Planning for the Society Development", Alexandria, University Knowledge House.

- Othman, Salwa (2003), "Individual service in the surrounding area of social service-the theoretical Concepts and Practical Trends", Alexandria, Modern University Office, p. 132

- Qamar, Essam Tawfiq and et al. (2008), "An Introduction to the Study of Arab Society", Amman, Jordan, Dar AlFikr.

- UNDP and The Arab Fund for Economic and Social Development (2002), Arab Human Development Report, Amman, Jordan

- Work Team (2008), "In regard to the Poverty in Northern District (Al-Nasr), Irbid - An Analytical Descriptive Study", Unpublished Study, Directorate of Social Development, Irbid, Jordan

- World Bank (2006), "Poverty Maps and the Policy to Fight it", Amman, Jordan

- Zubaidi, Fatima (2006), "Trends of University of Jordan Students toward Volunteering-Field Study", Unpublished Master Thesis, University of Jordan. 